\title{
English translation of abdullah qadiri's novel "days gone by" and its reflection skills
}

\author{
Feruza Kabilova ${ }^{1}$, Turayeva Khurshida Tokhirovna ${ }^{2}$ \\ ${ }^{1}$ A teacher of ESP for Humanitarian Subjects, Bukhara State University \\ ${ }^{2} A$ teacher of English literature department, Bukhara State University
}

\begin{abstract}
The depiction of natural landscapes given in works of art is one of the factors that demonstrate the creative artistic skill. Because in the depiction of natural landscapes, the artist's attitude to the space he captures, how much he knows the place, how deeply he feels the world of heroes and the environment in which they live. Therefore, the depiction of natural landscapes is an integral part of the work of art.

Keywords: The depiction of natural landscapes, artist's attitude, world of heroes, figurative features.

\section{INTRODUCTION}

In a work of art, the author uses visual and expressive means to achieve his goal. While the natural landscapes in a work are the means by which the reader can imagine something, feel a certain feeling, see, hear something, and form images in the human mind, the different meanings of words and phrases in the play, figurative features, methods of expressing events in different ways - are expressive means.

In literary translation, the repetition of visual aids and the problem of word choice require great skill on the part of the translator. "The translator, in order to recreate the work in another language, ie in the native language, develops the author's idea, absorbs it, and then chooses an alternative word depending on the nature of the text, which means meaning, sound, form, stylistic alternative, anxious to express the original idea as fully as possible," wrote Gaybulla Salomov.
\end{abstract}

\section{LITERATURE REVIEW}

The aspects of a writer's skill are determined by the means of artistic imagery and expression used in the creation of the work. One such tool is the depiction of nature, which plays an important role in a work of art. The uniqueness of nature is reflected in man, in his psyche. When a person is born, he is in harmony with nature, enjoying its whims and beauty. It is only human nature to be inspired by nature. Man creates his own impressions of the beauties of nature. Only the masters of art: the writer and the poet, using the means of artistic expression, the artist, using a variety of colors, can express these impressions in the works. No matter what we read, we always come across a picture of nature. A true artist portrays man in harmony with Mother Nature. When a writer creates a work, he looks at every event, landscape, and reality in general. Based on the idea of the work, he chooses the appropriate detail and uses that selected detail to express the idea that plays a significant role in the content of the work. For example, when depicting nature in works of art, artists often refer to the image of rain, which is unique, in keeping with their mood, taking into account the situation: "soft, spotless raindrops", "black rain", "lightning", "black rain", "lightning" images such as "cold raindrops" and "heavy rain" indicate negative states in the human psyche, fear, inner turmoil, danger, or depression. In such images, the artist subjugates the rain, which is a natural phenomenon, to the will of the work, the inner feelings of the characters or the protagonist, the attitude to reality through this image, and the artist's unique style. Much depends on the idea expressed in the play, the chosen theme, the description of events. Unless the translator identifies these aspects before embarking on the translation, the work cannot "find its way to the heart," that is, it cannot convey the author's intent to the reader. As a result, the author's style in translation may be compromised.

\section{ANALYSIS}

Abdullah Qadiri often uses animation, analogies and adjectives to describe nature. For example, an excerpt from the novel's "A Living News and a Horrible Night" section:

"Oyning o 'n beshlari bo 'lsa-da, havoning bulutlig'i bilan oy ko 'rinmas, chin ma'nosi bilan qorong'i kuzning qorong'i bir tuni edi. Bir necha yuz yillardan beri yashab favqulodda zo 'rayib ketgan "Xo 'ja Maoz" mozorining chakalagi bu qorong 'iliqqa bir manba' kabi edi. Kuchlik bir yel turg'an, qandaydir bir ishga hozirlang'an kabi to 'rt tomong'a yugurib yurar edi. Mozor chakaligining bir burchagida tutab yotg'an to 'nka yonida sochlari o 'sib soqolig'a qo 'shilib ketgan bir devona bu mudhish qorong'iliqqa qarshi kurashkan kabi gulxanni yondirishg'a tirishar, gulxan tavaragidan aylanib qo 'lidag'i kasavi bilan to 'rt tomonidan kovlar edi. Yel borg'an sari kuchlana bordi, chakalak tartibsiz holg'a kirib ketdi, bitta- yarimta to 'kilmay qolg'an yaproqlar shitir-shitir to 'kilishka oldilar, qarg'a va zog'chalar ayni uyqu zamonida tinchsizlangani uchun yelga qarshi namoyish qilg'andek g'o-g'u bila chakalak ustidan aylana boshladilar. Yel kuchaygandan kuchayib borar va shu nusbatda mozor ichi ham yana bir qat qo 'rqunch holg'a kirar edi, yel ketma-ket bo 'kurar, bunga chiday olmag'an shox-shabbalar qars- qurs sinar, keksa yog'ochlar g'iyq- 
g'iyq etib yolborish tovshi chiqarar edilar. Yel ortiqcha bir g'azab ustida edi, yer yuzidagi tikkaygan narsani bukibyanchib tashlamoqchi bo 'lgandek pishqirar edi..." [1,222-223]

Let's compare this translation with the original:

"Although the moon was already full, its pale orb was hidden behind thick clouds. Night fell, a true ebony, autumn night. The darkness seemed to seep from the hundred year old grove growing profusely by the Hodja Maoz graveyard. The wind picked up, blowing from all sides now, as though wanting to whip everything away somewhere. In a murky corner of the grove, a strange figure lurked by one of the graves. Unkempt and wild, his, hair dishevelled, he circled a smouldering stump, poking it with a stick, trying to coax the fire to life. The wind raged, the trees swayed this way and that, noisily shaking off their last leaves. Rooks and ravens, startled from their roosts, circled above, cawing as if protesting against the storm. The wind gained strength, howling and wailing. Unable to withstand this onslaught, the old trees in the graveyard screeched so pitifully as their branches snapped off with a crack that the eerie Cimmerian darkness which shrouded everything from sight took on an even more terrifying aspect. Finally, whipped into a frenzy, the wind roared with such a furious forse as if seeking to crush and crumple anything which stood in its path. It toppled one of the plane trees with a mighty thud, causing the ground to tremble, snatched the embers of the holy fool's fire and flung them into the thicket, filling the grove with sparks and lighting the graveyard up like a ghoulish picture. Then, without warning, as though its fury had been for this alone, the wind suddenly slackened, quietened...” [2, 206]

The success of the translator in this passage is that the phrase "Bir necha yuz yillardan beri yashab favqulodda zo 'rayib ketgan "Xo 'ja Maoz” mozorining chakalagi bu qorong'iliqqa bir manba' kabi edi" was translated as "The darkness seemed to seep from the hundred-year-old growing grove profusely by the Hodja Maoz graveyard" - "bir necha yuz yillardan beri bolta ko 'rmaganligi uchun juda qarovsiz bo'lib qolgan "Xo'ja Maoz" mozorining chakalagi ham bu qorong'ulikka bir manba kabi ko'rinardi". This means that in this case, "favqulodda zo 'rayib ketgan "Xo 'ja Maoz" mozorining chakalagi", which is extremely strong, is translated as "bolta ko "rmaganligi uchun juda qarovsiz bo "lib qolgan "Xo 'ja Maoz" mozorining chakalagi", and in terms of meaning, the content of the original text is fully covered in the translation.

The phrase “...yel ketma-ket bo 'kurar, bunga chiday olmag'an shox-shabbalar qars- qurs sinar, keksa yog'ochlar g'iyq-g'iyq etib yolborish tovshi chiqarar edilar..." was translated as "the roars and bellows of this ravenous beast gave no way to mercy. The rooks and ravens, buffeted above the grove in horror for half an hour, now cawed to one another as though sharing news of the quieting storm, and swooped back to their branches" here, too, the meaning is fully covered, but some words are omitted. For example, the phrase "shox-shabbalar qars-qurs sinar" was completely translated as swooped back to their branches, and in the phrase keksa yog'ochlar g'iyq-g'iyq etib yolborish tovshi chiqarar edilar compound, the phrase keksa yog'ochlar is omitted and yolborish tovshi chiqarar edilar compound, which belongs to it, connects to the previous compound to form its logical continuation. That is, there are branches that are broken and begging for the wind.

\section{DISCUSSION}

There are shortcomings in the translation of some of the plates quoted in the passage. For example, in the original text, the phrase "Oyning o'n beshlari bo 'lsa-da, havoning bulutlig'i bilan oy ko 'rinmas, chin ma'nosi bilan qorong' $i$ kuzning qorong'i bir tuni edi" "although the moon was already full, its pale orb was hidden behind thick clouds. Night fell, true ebony autumn night" represented by two sentences in the form. Here the author describes a dark autumn night when the moon's face is covered with clouds, and in the translation, “chin ma'nosi bilan qorong'i kuzning qorong'i bir tuni edi" the phrase "a true ebony autumn night" - "kuzning bir tuni". At this point, the author misses a dark night of dark autumn that he wants to emphasize.

Let's continue the analysis: "Yel ortiqcha bir g'azab ustida edi, yer yuzidagi tikkaygan narsani bukib-yanchib tashlamoqchi bo "lgandek pishqirar edi" translated into Turkish as "The wind picked up, blowing from all sides now, as though wanting to whip everything away somewhere" - "shamol ko tarilib, har taraftdagi hamma narsani havoga sovurardi xuddiki hamma narsani biror yerga supurib tashlamoqchi bulgandek”. From this we can see that the translator tried to express the sentence from the content, avoiding the literal translation, and he succeeded.

Here is an example from the "Black Days" section:

"Kuz kunlarining oyog'i va qish kunlarining boshi edi. Daraxtlardagi sariq barglar to 'kilib tugalgan, yer yuzi o 'zining qishqi sariq kiyimini kiygan edi. To 'rt tomonining o'ralg'anlig' $i$ soyasida yaproqlarini to 'kilishdan saqlab qolg'an bu gilos yog'ochlari ham bu kun tungi qora sovuqqa chidalmay, yelning ozgina harakati bilanda barglarini shirt-shirt uzib tashlamoqda edilar. Havo ochiq bo 'lib, quyosh tuzukkina ko 'tarilgan, ammo uning o 'zi ham bu kun uncha ta'siri yo 'q, bu kungi qora sovuq quyosh kuchini-da keskan edi." [1,211]

Abdullah Qadiri is a broad-minded artist. In this passage, the author describes the image of nature in connection with the end of the autumn season and the onset of winter with very beautiful analogies and Uzbek grace. They tremble in the wind as if they were shivering from the cold. Let us now compare and analyze this passage with the English translation:

"It was the last day of autumn, winter was waiting just around the corner.The trees had already shed their yellow leaves, which were now spread over the earth like a golden carpet, preparing the ground for its winter sleep.Even the cherry trees, sheltered from the windby walls and bulidings and clinging to their foliage for longer, couldnot withstand the chill of the late autumn nights and now murmuring, they let their leaves drop at the wind's slightest flutter.The sky was clear, the sun had already climbed high, but its warmth was meager, the chill air seeming to sap the 
strength from its rays. " $[2,194]$

The translator was able to understand the original phrase "Kuz kunlarining oyog' $i$ va qish kunlarining boshi edi..." and in the translation: "It was the last day of autumn, winter was waiting just around the corner." (The English text reads: "Kuz kunlari nihoyasiga yetgan. Qish kelishi arafasi edi") The translation shows how much the translator understood the phenomenon of nature. "Daraxtlardagi sariq barglar to 'kilib tugalgan, yer yuzi o 'zining qishqi sariq kiyimini kiygan edi..." was translated as "The trees had already shed their yellow leaves, which were now spreading over the earth like a golden carpet..." (meaning:" The trees shed their yellow leaves, and the earth was covered with a golden carpet"). The translator used the phrase "the earth was covered with a golden carpet" as used by the author. "Havo ochiq bo 'lib, quyosh tuzukkina ko 'tarilgan, ammo uning o'zi ham bu kun uncha ta'siri yo 'q, bu kungi qora sovuq quyosh kuchini-da keskan edi..." was translated as "The sky was clear, the sun had already climbed high, but its warmth was meager, the chill air seeming to sap the strength from its rays."

(The English text reads: "The sky was clear, the sun had already risen, but the sun's rays had little effect, and the strong cold was overcoming the sun's rays.") At this point, the interpreter is in original: the phrase "quyosh tuzukkina ko 'tarilgan, ammo uning o 'zi ham bu kun uncha ta'siri yo 'q, bu kungi qora sovuq quyosh kuchini-da keskan edi” "was translated as "The sky was clear, the sun had already climbed high, but its warmth was meager, the chill air seeming to sap the strength from its rays." has managed to preserve the meaning by translating it into a compound sentence.

\section{CONCLUSION}

At the same time, important work is being done to translate the masterpieces of Uzbek literature into foreign languages. The Department of Literary Translation and International Relations under the Writers' Union of Uzbekistan, in cooperation with universities in the capital and regions, has established a "School of Young Translators" to support young artists in the country. The first translations were published by Adib Publishing House, the World Literature magazine was published regularly, and many other events took place. It is no secret that the honorable task of presenting examples of Uzbek literature in foreign languages and the best works of world literature in our native language depends on the talent and enthusiasm of today's young generation.

\section{REFERENCES:}

1. Hamidov H. "Representation of nature in the translation of a work of art", Translation issues (Collection of scientific articles, №9 April 26, 2012) pp. 75-77.

2. Aminova L. Issues of artistic mastery in the works of Turkish writer Yashar Kemal, - Ph.D. written dissertation for an academic degree, T .: 2003, Pp. 8-35.

3. Salomov G., Art of Translation, Tashkent, 1973, $57 \mathrm{p}$.

4. Sharipov J. Some issues of poetic translation. T .: Fan. 1959. 32-33pp.

5. Ahmedov B. History is the mother of truth. T .: Young Guard. 1989. - p.46

6. Ibrohimova Sh. Giving a portrait of a hero in the translation of works of art. Translation issues (Collection of scientific articles, №9 April 26, 2012 pp. 96-97.

7. Dragomeratskaya N.V. artistic historicism as a theoretical problem // Philological sciences. 1977. No. 4, $17-22 \mathrm{p}$.

8. Timofeev A. Foundations of the theory of literature. M.: Pros. 1971. - 156-p.

9. Chukovsky K.I. Vysokos art // Umarov. From the book the art of analysis. T .: G`. G'ulom. 1978, 74-p.

10. Gachechiladze G.R. Literary translation and literary relationships. M :. SP. 1980. 149-p.

11. Lomidze G.I. Contemporary, ed. 2nd, Moscow: Acad. Nauk. 1974.78-p.

12. Lilova A. Introduction to the general theory of translation. M.: Vyslik. 1985.103-p. 